\title{
KEBUTUHAN KARBOHIDRAT UNTUK PERTUMBUHAN YUWANA IKAN KERAPU BEBEK, Cromileptes altivelis
}

\author{
Ketut Suwirya*), Nyoman Adiasmara Giri"), Mohammad Marzuqi"), dan Tridjoko*)
}

\begin{abstract}
ABSTRAK
Karbohidrat telah banyak diketahui sebagai sumber energi. Kemampuan ikan untuk memanfaatkan karbohidrat sangat tergantung pada jenis ikan. Untuk mengetahui kebutuhan karbohidrat ikan kerapu bebek maka yuwana ikan kerapu bebek diberi pakan dengan dekstrin sebagai sumber karbohidrat pada kadar 0\%; 7\%; 14\%; $21 \%$; dan $28 \%$. Yuwana ikan kerapu bebek yang dipelihara dalam bak silinder ukuran $30 \mathrm{~L}$ dengan sistem air mengalir selama 63 hari. Kepadatan ikan yang mempunyai bobot rata-rata $8 \pm 0,33 \mathrm{~g}$ adalah 11 ekor per bak. Ikan diberi pakan dua kali per hari sampai kenyang. Hasil percobaan menunjukkan bahwa kadar karbohidrat berpangaruh nyata terhadap pertumbuhan, efisiensi pakan, dan rasio konversi pakan $(P<0,05)$. Yuwana ikan kerapu bebek diberi pakan dengan kandungan karbohidrat $7 \%$; $14 \%$; $21 \%$; dan $28 \%$ pertambahan bobot yang tidak berbeda nyata, tetapi ikan yang diberi pakan tanpa karbohidrat mempunyai pertambahan bobot yang lebih rendah dibandingkan ikan yang diberi pakan dengan kadar karbohidrat 7\%-28\% $(P<0,05)$. Ikan kerapu bebek yang diberi pakan dengan kadar karbohidrat $14 \%-28 \%$ mempunyai efisiensi pakan yang lebih tinggi dari ikan yang diberi pakan tanpa karbohidrat. Kadar glikogen hati mempunyai hubungan dengan kadar karbohidrat pakan di mana ikan yang diberi pakan dengan kadar karbohidrat $0 \% ; 7 \% ; 14 \% ; 21 \%$; dan $28 \%$ mempunyai kandungan glikogen hati berturut-turut 2,54\%; 5,28\%; 7,84\%; 7,94\%; dan 8,40\%. Hasil percobaan ini menunjukkan bahwa kebutuhan ikan kerapu bebek akan karbohidrat adalah $14 \%$.
\end{abstract}

ABSTRACT: Carbohydrate requirement for growth of humpback grouper (Cromileptes altivelis) juvenile. By: Ketut Suwirya, Nyoman Adiasmara Giri, Mohammad Marzuqi, and Tridjoko

Carbohydrate is know as one of the energy important sources. Ability of fish to use carbohydrate strongly depend on the species. To identify carbohydrate requirement of humpback grouper. This research was done where humpback grouper juvenile were fed with experiment diets of $0 \%, 7 \%, 14 \%, 21 \%$, and $28 \%$ dietary carbohydrate levels. The source of carbohydrate in this experiment was dextrine. The juveniles were reared in $30 \mathrm{~L}$ cilinder tank with flow through system for 63 days. Fish with average body weight of $8.0 \pm 0.33 \mathrm{~g}$ were stocked in a density of 11 fish per tank. The fish were fed twice a day at libitum. The result showed that the dietary levels of carbohydrate affected the growth, feed efficiency, and feed convertion ratio $(P<0.05)$. Fish fed with diets with $7 \%, 14 \%, 21 \%$, and $28 \%$ dietary carbohydrate were not significantly different in weight gain, but those fed with diets without carbohydrate had significantly lower weight gain compared to those fed with diet of $7 \%-28 \%$ dietary carbohydrate $(P<0.05)$. Diet with $14 \%$ dietary carbohydrate had significantly higher feed efficiency and lower feed convertion ratio than that without carbohydrate. Feed convertion ratios diets with $14.0 \%, 21.0 \%$, and $28.0 \%$ dietary levels of carbohydrate were not significantly different $(P<0.05)$. Glycogen content of liver had a corelation with dietary carbohydrate. Diets with $0 \%, 7 \%, 14 \%, 21 \%$, and $28 \%$ dietary carbohydrate showed glycogen contents of $2.54 \%, 5.28 \%, 7.84 \%, 7.94 \%$, and $8.40 \%$ respectively. The result of experiment indicated that the requirement of carbohydrate for humpback grouper was $14 \%$.

KEYWORDS: carbohydrate, growth, feed efficiency

\section{PENDAHULUAN}

Ikan kerapu bebek Cromileptes altivelis merupakan jenis ikan yang hidup di perairan karang. Ikan ini merupakan salah satu komoditas perikanan yang bernilai tinggi, terutama di pasar Asia. Usaha penangkapan ikan ini di alam semakin meningkat sejalan dengan permintaan pasar, sehingga dikhawatirkan populasinya cenderung menurun. Untuk mengantisipasi hal ini maka perlu didorong usaha budi dayanya. Akhir-akhir ini teknologi pembenihan ikan kerapu bebek telah berhasil dikembangkan dan telah berhasil memproduksi benih untuk keperluan budi daya (Trijoko et al., 1996; Aslianti, 1996; Sugama et

Peneliti pada Balai Besar Riset Perikanan Budidaya Laut, Gondol 
al., 1998). Di samping benih, komponen budi daya yang memegang peranan penting adalah pakan. Dalam beberapa tahun terakhir telah diteliti penggunaan pakan buatan pada ikan kerapu bebek (Suwirya et al., 1998); kebutuhan protein, lemak, dan vitamin $C$ dalam pakan (Giri et al., 1999); n-3 HUFA dalam pakan (Suwirya et al., 2001). Dari hasil percobaan tersebut ternyata kerapu bebek memerlukan protein yang cukup tinggi yaitu $54,2 \%$; sedangkan protein merupakan nutrien pakan yang cukup mahal. Oleh karena itu untuk efisiensi penggunaan protein maka nutrien pakan yang juga penting dan harus mendapat perhatian dalam pengembangan pakan ikan kerapu adalah karbohidrat, sebagai salah satu sumber energi.

Telah banyak diketahui bahwa ikan-ikan herbivora dan omnivora dapat memanfaatkan karbohidrat pakan secara efisien. Oleh karena itu ikan-ikan tersebut dibudidayakan dengan pakan yang mengandung karbohidrat cukup tinggi. Sedangkan secara umum diasumsikan bahwa penambahan karbohidrat pada pakan ikan karnivora seperti ikan yellowtailtidak efektif, namun perlu dicoba pada ikan kerapu bebek, karena kesimpulan tersebut tidak didasarkan pada aspek biokimia dari ikan. Laporan Phillips et al. (1946) dalam Phillips (1972) menyatakan bahwa ikan trout memanfaatkan karbohidrat pakan pada kadar terbatas. Kadar karbohidrat yang baik dalam pakan adalah $12 \%$, dan ditemukan juga bahwa kadar karbohidrat dalam pakan yang tinggi akan meningkatkan akumulasi glikogen pada hati. Ikan trout secara fisiologi tidak dapat memanfaatkan kadar karbohidrat pakan yang tinggi dan karbohidrat hanya merupakan sumber energi yang terbatas.

Berlainan dengan ikan trout bahwa ikan salmon dapat memanfaatkan kadar karbohidrat pakan relatif tinggi tanpa menyebabkan gangguan fisiologis. Peningkatan kadar karbohidrat dalam pakan akan menyebabkan meningkatnya kadar glikogen hati, namun peningkatan ini tidak menunjukkan pengaruh yang berbahaya (Buhler \& Halver, 1961 dalam Phillips, 1972). Hal ini menunjukkan bahwa pemanfaatan karbohidrat pakan sangat bergantung pada jenis ikan.

Tujuan dari percobaan ini adalah mengetahui kebutuhan optimum karbohidrat untuk yuwana ikan kerapu bebek.

\section{BAHAN DAN METODE}

Sumber karbohidrat yang digunakan pada percobaan ini adalah dekstrin. Pakan percobaan diformulasi sehingga mempunyai kandungan karbohidrat berbeda yaitu $0 \% ; 7 \% ; 14 \%$; $21 \%$; dan $28 \%$ (Tabel 1). Semua pakan mempunyai kadar protein dan lemak yang sama. Untuk penyeimbang dalam formulasi digunakan selulose. Pakan dibuat dalam bentuk pellet dan dikeringkan dengan freeze dryer. Pakan disimpan pada suhu $4^{\circ} \mathrm{C}$ sebelum dan selama percobaan.

Yuwana ikan kerapu bebek diperoleh dari hasil pemeliharaan di Balai Besar Riset Budidaya Laut Gondol. Sebagai wadah percobaan digunakan 15 buah bak polikarbonat dengan volume $30 \mathrm{~L}$ yang dilengkapi aerasi dan sistem air mengalir dengan pergantian air mencapai $20 \mathrm{~L}$ per 30 menit. Dalam setiap bak dipelihara 11 ekor yuwana dengan bobot rata-rata 8,00 $\pm 0,33 \mathrm{~g}$. Selama 63 hari percobaan, ikan diberi pakan secara perlahan-lahan dua kali sehari sampai ikan tidak mau makan (adlibitum). Bak-bak pemeliharaan dibersihkan tiap pagi hari sesudah ikan diberi pakan. Percobaan dirancang menggunakan rancangan acak lengkap dengan lima perlakuan (Tabel 1) dan masingmasing perlakuan mendapat tiga ulangan.

Untuk mengetahui pertumbuhan ikan, setiap 7 hari dilakukan pengukuran bobot ikan.Penimbangan dilakukan terhadap semua ikan dalam setiap bak secara individu. Pada akhir percobaan, dua ekor ikan sebagai contoh diambil dari setiap bak. Hati dan daging ikan contoh segera dipisahkan untuk dikeringkan pada alat pengering beku (freeze dryer). Kadar glikogen pada hati dan daging ditentukan dengan metode Wedemeyer \& Yasutaka (1977). Data pertumbuhan, efisiensi, konversi pakan, dan kadar glikogen pada hati dan daging ikan dianalisis menggunakan analisis ragam dan uji Tukey's pada taraf nyata 95\% (Steel \& Torrie, 1980).

\section{HASIL DAN BAHASAN}

Kandungan karbohidrat (dekstrin) dalam pakan berpengaruh nyata $(P<0,05)$ terhadap pertumbuhan yuwana ikan kerapu bebek (Tabel 2). Kadar karbohidrat (dekstrin) pakan 0,0\% memberikan pertumbuhan yang lebih rendah pada yuwana ikan kerapu bebek dibandingkan dengan pakan yang mengandung karbohidrat $14 \%$ sampai $28 \%$, sedang pakan dengan kadar karbohidrat $14 \% ; 21 \%$; dan $28 \%$ memberikan pertumbuhan yang tidak berbeda nyata pada yuwana kerapu bebek $(P>0,05)$. Hal ini menunjukkan bahwa kadar dekstrin $14 \%$ atau kadar bahan ekstrak tanpa nitrogen (BETN) 15,66\% dalam pakan adalah optimum untuk pertumbuhan yuwana ikan kerapu bebek.

Dari Tabel 2 juga menunjukkan bahwa yuwana ikan kerapu yang diberi pakan dengan kadar karbohidrat $0,0 \%$ memberikan efisiensi pakan yang paling rendah dan rasio konversi pakan paling tinggi dari semua pakan percobaan $(P<0,05)$. Hal ini menunjukkan dekstrin pakan dapat meningkatkan efisiensi pakan atau menurunkan rasio konversi pakan. Hal yang serupa ditemui oleh Anderson et al. (1984) terhadap ikan nila (Oreochromis niloticus), bahwa penggunaan dekstrin sebagai sumber karbohidrat meningkatkan 
Tabel 1. Komposisi pakan percobaan (\%)

Table 1. Composition of experimental diets (\%)

\begin{tabular}{lrrrrr}
\hline \multirow{1}{*}{$\begin{array}{c}\text { Bahan pakan } \\
\text { Ingredients }\end{array}$} & $\mathbf{5}$ & $\mathbf{2}$ & $\mathbf{3}$ & $\mathbf{4}$ & $\mathbf{5}$ \\
\cline { 2 - 6 } & 17.48 & 17.48 & 17.48 & 17.48 & 17.48 \\
\hline Kasein (casein) & 36.07 & 36.07 & 36.07 & 36.07 & 36.07 \\
Tepung ikan (fish meal) & 7.78 & 7.78 & 7.78 & 7.78 & 7.78 \\
Tepung rebon (tiny shrimp meal) & 4.95 & 4.95 & 4.95 & 4.95 & 4.95 \\
Minyak cumi (squid oil) & 0.10 & 0.10 & 0.10 & 0.10 & 0.10 \\
Asthaxanthin & 1.30 & 1.30 & 1.30 & 1.30 & 1.30 \\
Vitamin mix* & 1.45 & 1.45 & 1.45 & 1.45 & 1.45 \\
Mineral mix* & 0.00 & 7.00 & 14.00 & 21.00 & 28.00 \\
Dekstrin (dextrin) & 28.00 & 21.00 & 14.00 & 7.00 & 0.00 \\
Selulosa (cellulose) & 2.91 & 2.91 & 2.91 & 2.91 & 2.91 \\
CMC & & & & & \\
\hline Proksimat (proximate) & 50.40 & 50.65 & 50.45 & 50.61 & 50.92 \\
Protein & 9.39 & 9.31 & 9.18 & 9.04 & 9.17 \\
Lemak (lipid) & 10.55 & 10.43 & 10.26 & 9.49 & 10.03 \\
Abu (ash) & 28.50 & 21.40 & 14.45 & 8.90 & 1.20 \\
Serat (fibre) & 1.16 & 8.21 & 15.66 & 21.96 & 28.68 \\
BETN (N-free extract) & 3.78 & 4.07 & 4.38 & 4.65 & 4.91 \\
Energi (Kkal/g pakan) & & & & & \\
Energy (Kcal/g diet)*** & & & & & \\
\hline
\end{tabular}

- Vitamin Mix (mg/100 g pakan)/vitamin mix (mg/100 g diet): thiamin-HCl, 5.0; riboflavin, 5.0; Ca-pantothenate, 10.0; niacin, 2.0; pyridoxin- $\mathrm{HCl}, 4.0$; biotin, 0.6; folic acid, 1.5; cyanocobalamin, 0.01; inositol, 200; p-aminobenzoic acid, 5.0; menadion, 4.0; b-carotin, 15.0; calciferol, 1.9; a-tocopherol, 25.0; vitamin C (phosphitan), 120; choline chloride, 900.

** Mineral mix (mg/100 garam pakan)/mineralmix (mg/100 g dieft): $\mathrm{KH}_{2} \mathrm{PO}_{4}, 412 ; \mathrm{CaCO}_{4}, 282 ; \mathrm{Ca}\left(\mathrm{H}_{2} \mathrm{PO}_{4}\right)$, $618 ; \mathrm{FeCl}_{2}, 166 ; \mathrm{ZnSO}_{4}, 9.99 ; \mathrm{MnSO}_{4}, 6.3 ; \mathrm{CuSO}_{4}, 2 ; \mathrm{CoSO}_{4}, 0.05 ; \mathrm{KJ}, 0.15$

*** Total energi dihitung berdasarkan: protein, $5.65 \mathrm{kkal} / \mathrm{g}$; lemak, $9.45 \mathrm{kkal} / \mathrm{g}$, karbohidrat, $4.10 \mathrm{kkal} / \mathrm{g}$ (Total energy based on energy content of protein $=5.65 \mathrm{kcal} / \mathrm{g}$; lipid $=9.45 \mathrm{kcal} / \mathrm{g}$; carbohydrate, 4.10 $\mathrm{kcal} / \mathrm{g}$ )

Tabel 2. Pertumbuhan, efisiensi, dan konversi pakan yuwana ikan kerapu bebek yang diberi pakan percobaan Table 2. Growth, feed efficiency, and convertion ratio of juvenile humpback grouper fed experimental diets

\begin{tabular}{cccc}
\hline $\begin{array}{c}\text { Kadar karbohidrat } \\
\text { Carbohydrate level (\%)* }\end{array}$ & $\begin{array}{c}\text { Pertambahan bobot } \\
\text { Weight gain (\%)* }^{*}\end{array}$ & $\begin{array}{c}\text { Efisiensi pakan } \\
\text { Feed efficiency* }^{*}\end{array}$ & $\begin{array}{c}\text { Konversi pakan } \\
\text { FCR }^{*}\end{array}$ \\
\hline 0.00 & $222.2 \pm 5.11^{\mathrm{a}}$ & $0.77 \pm 0.04^{\mathrm{a}}$ & $1.37 \pm 0.06^{\mathrm{b}}$ \\
7.00 & $251.5 \pm 8.79^{\mathrm{b}}$ & $0.86 \pm 0.03^{\mathrm{ab}}$ & $1.16 \pm 0.04^{\mathrm{ab}}$ \\
14.00 & $268.1 \pm 8.22^{\mathrm{b}}$ & $0.92 \pm 0.09^{\mathrm{b}}$ & $1.02 \pm 0.07^{\mathrm{a}}$ \\
21.00 & $249.8 \pm 9.94^{\mathrm{b}}$ & $0.93 \pm 0.05^{\mathrm{b}}$ & $1.03 \pm 0.05^{\mathrm{a}}$ \\
28.00 & $259.3 \pm 14.59^{\mathrm{b}}$ & $0.91 \pm 0.01^{\mathrm{b}}$ & $1.07 \pm 0.03^{\mathrm{a}}$ \\
\hline
\end{tabular}

* Nilai dalam kolom yang diikuti oleh huruf yang sama tidak berbeda nyata $(P>0,05)$ /value in column followed by the same superscript are not significantly different $(P>0.05)$

efisiensi pakan dan menurunkan konversi pakan. Kim \& Kuashik (1992) juga mencatat bahwa penggunaan tepung jagung dalam bentuk gel sebagai sumber karbohidrat untuk ikan rainbow trout (Oncorhynchus mykiss) meningkatkan rasio efisiensi protein. Hasil penelitian Kaushik \& Teles (1985) dalam Kim \&
Kaushik (1992) mencatat bahwa penggunaan tepung jagung bentuk gelatin dalam ransum ikan Rainbow trout sebanyak $30 \%$ dapat memperbaiki penggunaan protein, diperlihatkan dengan menurunnya nitrogen yang disekresikan. Di samping itu juga menurut Anderson et al. (1982) peningkatan konversi pakan dan 
efisiensi pakan berkaitan dengan ketersediaan energi karbohidrat yang menekan penggunaan sumber energi dari protein. Namun nilai nutrisi dari karbohidrat ini sangat tergantung dari spesies ikan-ikan (Wilson, 1994).

Dalam kasus ikan mas yang diberi pakan dengan kandungan karbohidrat 3\%-4\% dan protein $28 \%-63 \%$, kecernaan karbohidrat dan protein pada ikan mas adalah $87 \%-91 \%$ dan $88 \%-89 \%$. Kecernaan protein pakan pada ikan mas adalah konstan dan tidak dipengaruhi oleh kadar karbohidrat dalam pakan (Shimeno, 1974; Shimeno et al., 1977). Hasil ini didukung oleh hasil percobaan Ogeno \& Chen (1973) bahwa ikan mas dapat mencerna dan mengabsorbsi nutrien secara efektif pada berbagai kadar karbohidrat pakan. Hasil yang sangat kontras ditunjukkan pada percobaan ikan yellowtail (Seriola quinqueradiata) muda dengan bobot tubuh $133 \mathrm{~g}$ dan diberikan pakan selama 30 hari (Shimeno et al., 1979). Hasil yang diperoleh menunjukkan bahwa kecernaan karbohidrat dari pakan yang mengandung $9 \%$ starch adalah hanya $57 \%$, dan kecernaannya cenderung menurun dengan meningkatnya kandungan karbohidrat pakan. Di samping itu, kecernaan protein juga menurun dari $84 \%$ menjadi $56 \%$ dengan meningkatnya karbohidrat pakan dari $10 \%$ menjadi $40 \%$. Kecernaan protein dan karbohidrat pakan sangat rendah pada kadar karbohidrat pakan $40 \%$. Rendahnya kecernaan tersebut karena rendahnya aktivitas enzim yang karbohidrat 10\%-20\% mempunyai pertumbuhan, efisiensi pakan, dan retensi protein yang lebih tinggi dibandingkan dengan ikan yang diberi pakan tanpa mengandung karbohidrat.

Kemampuan memanfaatkan karbohidrat pakan bergantung pada jenis ikan. Hal ini ditunjukkan pada ikan Calta calta dan Labio rahita yang pertumbuhan maksimum diberi pakan dengan kandungan karbohidrat $36 \%$, dan ikan Cirrhinus mrigalla kandungan karbohidrat pakan yang optimum adalah 27\% (Ernullah \& Jufri, 1998).

Kandungan glikogen dalam hati dan daging ikan kerapu bebek yang diberi pakan dengan kadar karbohidrat (dekstrin) yang berbeda disajikan pada Tabel 3. Kadar karbohidrat dalam pakan berpengaruh nyata terhadap kandungan glikogen pada hati dan daging ikan kerapu bebek $(P<0,05)$. Kadar glikogen hati ikan kerapu bebek yang diberi pakan dengan kadar karbohidrat $7 \%$ adalah $5,28 \pm 0,044 \%$ lebih tinggi dari ikan kerapu yang diberi pakan dengan kadar karbohidrat $0,0 \%(2,54 \pm 0,97 \%)$; namun lebih rendah dari ikan yang diberi pakan dengan kandungan karbohidrat $14 \%(7,84 \pm 0,56 \%)$. Peningkatan kadar karbohidrat pakan dari $14 \%$ sampai $28 \%$ ternyata tidak memberikan perubahan terhadap kandungan glikogen hati ikan kerapu bebek (Tabel 3). Hasil penelitian Shimeno et al. (1979) pada ikan ekor kuning (Seriola quinqueradiata) yang berukuran $144 \mathrm{~g}$ diberi pakan dengan kadar karbohidrat berbeda menunjukkan

Tabel 3. Kandungan lemak, glikogen pada daging, hati yuwana ikan kerapu bebek yang diberi pakan percobaan Table 3. The content of lipid, glycogen in the mussle and liver of humpback grouper juvenile were fed with experiment feeds

\begin{tabular}{lccccc}
\hline \multirow{2}{*}{ Parameter } & \multicolumn{5}{c}{ Kadar karbohidrat pakan (Content of dietary carbohidrate) (\%) } \\
\cline { 2 - 6 } & $\mathbf{0}$ & $\mathbf{7}$ & $\mathbf{1 4}$ & $\mathbf{2 1}$ & $\mathbf{2 8}$ \\
\hline Hati (liver) & & & & & \\
- Glikogen (glycogen) (\%) & $2.54 \pm 0.97^{\mathrm{a}}$ & $5.28 \pm 0.44^{\mathrm{b}}$ & $7.84 \pm 0.56^{\mathrm{c}}$ & $7.96 \pm 0.31^{\mathrm{c}}$ & $8.40 \pm 0.2^{\mathrm{c}}$ \\
- Lemak (lipid) (\%) & $17.17 \pm 1.14^{\mathrm{a}}$ & $18.49 \pm 0.94^{\mathrm{ab}}$ & $19.84 \pm 0.55^{\mathrm{ab}}$ & $21.25 \pm 2.16^{\mathrm{b}}$ & $20.52 \pm 3.18$ \\
\hline Daging (mussle) & & & & & \\
- Glikogen (glycogen) (\%) & $0.01 \pm 0.01^{\mathrm{a}}$ & $0.04 \pm 0.02^{\mathrm{ab}}$ & $0.05 \pm 0.02^{\mathrm{b}}$ & $0.07 \pm 0.02^{\mathrm{b}}$ & $0.07 \pm 0.02^{\mathrm{b}}$ \\
- Lemak (lipid) (\%) & $16.37 \pm 1.37^{\mathrm{a}}$ & $17.85 \pm 1.65^{\mathrm{a}}$ & $18.92 \pm 1.98^{\mathrm{a}}$ & $18.40 \pm 0.74^{\mathrm{a}}$ & $19.76 \pm 3.90$ \\
- Hepatosomatik indeks & $2.07 \pm 0.28^{\mathrm{a}}$ & $3.51 \pm 0.07^{\mathrm{b}}$ & $3.63 \pm 0.27^{\mathrm{b}}$ & $3.41 \pm 0.44^{\mathrm{b}}$ & $3.46 \pm 0.64^{\mathrm{b}}$ \\
$\quad$ Hepatosomatic Index (HSI)(\%) & & & & & \\
\hline
\end{tabular}

* Nilai dalam baris yang diikuti oleh huruf yang sama tidak berbeda nyata $(\mathrm{P}<0,05) /$ values in lines followed by the same superscript are not significantly different $(P<0.05)$

terlibat dalam kecernaan dan absorbsi karbohidrat. Hasil percobaan Shimeno et al. (1979) juga menunjukkan bahwa ikan yellowtail dapat adaptasi pada pakan dengan kandungan karbohidrat $10 \%-20 \%$. Ikan yellowtailyang diberi pakan dengan kandungan bahwa kandungan glikogen hati berkorelasi dengan kandungan karbohidrat pakan. Ikan yellowtail yang diberi pakan dengan kandungan karbohidrat $0,0 \%$; $10 \%$; $20 \%$; dan $40 \%$ mempunyai kandungan glikogen hati masing-masing $3,8 \% ; 4,8 \% ; 5,4 \%$; dan $4,8 \%$. 
Kadar glikogen daging ikan kerapu bebek meningkat dengan peningkatan kadar karbohidrat pakan dari $0,0 \%$ sampai $14 \%$. Namun ikan yang diberi pakan dengan kadar karbohidrat $14 \%$ sampai $28 \%$
Kandungan karbohidarat dari jenis dekstrin dalam pakan kerapu bebek yang memberikan pertumbuhan terbaik adalah $14 \%$.

Tabel 4. Pengaruh kandungan karbohidrat pakan terhadap komposisi tubuh ikan kerapu bebek pada akhir percobaan (\% bobot kering)

Table 4. Effect of carbohidrate content of diets on body composition of humpback grouper at the end of experiment (\% dry weight)

\begin{tabular}{cccccc}
\hline $\begin{array}{c}\text { Karbohidrat pakan } \\
\text { Dietary carbohydrate (\%) }\end{array}$ & $\begin{array}{c}\text { Protein } \\
\text { Protein (\%) }\end{array}$ & $\begin{array}{c}\text { Lemak } \\
\text { Lipid (\%) }\end{array}$ & $\begin{array}{c}\text { Abu } \\
\text { Ash (\%) }\end{array}$ & $\begin{array}{c}\text { Serat } \\
\text { Fiber (\%) }\end{array}$ & $\begin{array}{c}\text { BETN } \\
\text { N-free extract (\%) }\end{array}$ \\
\hline 0.0 & $58.18^{\mathrm{a}}$ & $19.02^{\mathrm{a}}$ & $17.40^{\mathrm{a}}$ & $1.96^{\mathrm{a}}$ & $3.41^{\mathrm{a}}$ \\
7.0 & $57.15^{\mathrm{a}}$ & $20.64^{\mathrm{a}}$ & $17.04^{\mathrm{a}}$ & $2.04^{\mathrm{a}}$ & $3.13^{\mathrm{a}}$ \\
14.0 & $57.99^{\mathrm{a}}$ & $20.15^{\mathrm{a}}$ & $16.55^{\mathrm{a}}$ & $1.86^{\mathrm{a}}$ & $3.45^{\mathrm{a}}$ \\
21.0 & $58.03^{\mathrm{a}}$ & $19.50^{\mathrm{a}}$ & $16.03^{\mathrm{a}}$ & $2.17^{\mathrm{a}}$ & $4.28^{\mathrm{a}}$ \\
28.0 & $58.08^{\mathrm{a}}$ & $17.94^{\mathrm{a}}$ & $17.69^{\mathrm{a}}$ & $2.47^{\mathrm{a}}$ & $3.82^{\mathrm{a}}$ \\
\hline
\end{tabular}

* Nilai dalam kolom yang diikuti oleh huruf yang sama tidak berbeda nyata $(P>0,05)$

Value in column followed by the same superscript are not significant different $(P>0.05)$

menunjukkan bahwa kadar glikogen daging ikan sama (Tabel 3). Hasil pengamatan Shimeno et al., (1979) pada ikan yellowtailjuga menunjukkan hal yang sama. Hasil percobaan ini menunjukkan bahwa ikan kerapu bebek dapat memanfaatkan karbohidrat dalam bentuk dekstrin sebagai sumber energi.

Kadar karbohidrat dalam pakan nampaknya berpengaruh terhadap ukuran hati ikan kerapu bebek. $\mathrm{Hal}$ ini ditunjukkan oleh nilai hepatosomatik indeks (HSI). Ikan kerapu bebek yang diberi pakan tanpa karbohidrat mempunyai HSI yang lebih kecil dibandingkan dengan ikan yang diberi pakan dengan kadar karbohidrat 7\%-28\% (Tabel 3). Bobot hati ikan yang diberi pakan mengandung karbohidrat relatif lebih besar dibandingkan dengan ikan diberi pakan tanpa karbohidrat. Bobot hati ikan yang lebih besar tersebut karena digunakan sebagai penyimpan cadangan energi yang berupa glikogen.

Percobaan Shimeno et al. (1979) pada ikan yellowtail yang diberi pakan dengan kandungan karbohidrat $0,0 \% ; 10 \%$; $20 \%$; dan $40 \%$ diperoleh bahwa bobot hatinya meningkat masing-masing 4,36g; 6,68g; 6,73g; dan 4,33g. Hasil tersebut mempunyai pola yang sama dengan kerapu bebek.

Hasil analisis proksimat tubuh ikan kerapu bebek yang diberi pakan dengan kadar karbohidrat $0,0 \%$; $7 \% ; 14 \% ; 21 \%$; dan $28 \%$ menunjukkan bahwa kadar karbohidrat pakan tidak mempengaruhi komposisi tubuh ikan (Tabel 4).

\section{KESIMPULAN}

Ikan kerapu bebek (Cromileptes altivelis) dapat memanfaatkan dekstrin sebagai sumber energi.

\section{DAFTAR PUSTAKA}

Anderson, J., A.J. Jackson, A.J. Matty, and B.S. Capper. 1984. Effect of dietary carbohidrate and fibre on the tilapia (Oreochromis niloticus Linn). Aquaculture. 37:303-314.

Aslianti, T. 1996. Pemeliharaan larva kerapu bebek, Cromileptes altivelis, dengan padat penebaran berbeda. Jurnal Penelitian Perikanan Indonesia. 2: 6-12.

Ernullah and A.K. Jafri. 1998. Growth rate, feed convertion, and body composition of Calta calta, Labio rohita, and Cirrhinus mrigala fry fed diets of various carbohydrate to lipid ration. J. Word Aquaculture Soc. 29(1): 84-91.

Giri, N.A., K. Suwirya, dan M. Marzuqi. 1999. Kebutuhan protein, lemak, dan vitamin $C$ untuk yuwana ikan kerapu bebek (Cromileptes altivelis). Jurnal Penelitian Perikanan Indonesia. 5(3): 38-46.

Kim, J.D. and S.J. Kaushik. (1992). Contribution of digestible energy from carbohydrate (Oncorhyncus mykiss). Aquaculture. 106:161-169.

Ogeno,C. and M. Chen. 1973. Protein nutrition in fish -III, apparent and true digestibility of dietary protein in carp. Bull. Japan Soc. Sci. Fish. 39(6): 944-951.

Phillips Jr., A.M. 1972. Calorie and energy requirement. In J.E. Halver (Ed.) Fish Nutrition. Academic Press Inc, Washington. p. 2-28.

Shemino,S. 1974. Studies on carbohydrate metabolism in fishes. Rep. Fish. Lab., Kochi Univ. 2: 1-107.

Shemino, S., H. Hosokawa, and M. Takeda. 1977. Comparative studies on carbohydrate metabolism of yellow tail and carp. Bull. Jap. Soc. Sci. Fish. 43(2): 213217.

Shimeno, H., H. Hosokawa, and M. Takeda. 1979. The importance of carbohidrate in the diet of a carnivorous fish. Proc. World Symp. on Finfish Nutrition and 
Fishfeed Technology, Haburg, 20-23 June. 1: 127143.

Steel, R.G.D. and J.H. Torrie. 1980. Principles and Procedures of Statistics. McGrow Hill, New York, U.S.A.

Suwirya, K., N.A. Giri, dan M. Marzuqi. 1998. Penggunaan pakan buatan dalam pemeliharaan yuwana ikan kerapu bebek, Cromileptes altivelis, hasil

Suwirya, K. N.A. Giri, dan M. Marzuqi. 2001. Pengaruh n3 HUFA terhadap pertumbuhan dan efisiensi pakan yuwana ikan kerapu bebek, Cromileptes altivelis. In Sudradjat, A., E.S. Heruwati, A. Poernomo, A. Rukyani, J. Widodo, dan E. Danakusuma (Eds) Teknologi Budi Daya Laut dan Pengembangan Sea Farming di In- donesia, Depertemen Kelautan dan Perikanan. p. 201-206.

Trijoko, B. Slamet, D. Makatutu, dan K. Sugama. 1996. Pengamatan pemijahan dan perkembangan telur ikan kerapu bebek (Cromileptes altivelis) secara terkontrol. Jurnal Penelitian Perikanan Indonesia. 2(2): 55-62.

Wedemeyer, G.A. and W.T. Yasutake. 1977. Clinical methods for the assessment of the effects of environmental stress on fish health. Technical Papers of the U.S. Fish and Wildlife Service, Washington, D.C. 18 pp.

Wilson, R.P. 1994. Review: Utilization of dietary carbohydrate by fish. Aquaculture. 124:67-80. 